\title{
The Azokh Cave complex: Middle Pleistocene to Holocene human occupation in the Caucasus
}

\author{
Y. Fernández-Jalvo a,*, T. King ${ }^{b}$, P. Andrews ${ }^{c}$, L. Yepiskoposyan ${ }^{\text {d,e }}$, N. Moloney ${ }^{\text {a,b }}$, J. Murray ${ }^{\mathrm{f}}$, \\ P. Domínguez-Alonso ${ }^{g}$, L. Asryan ${ }^{\text {h }}$, P. Ditchfield ${ }^{i}, J^{\prime}$. van der Made ${ }^{a}$, T. Torres $^{j}$, P. Sevilla ${ }^{g}$, \\ M. Nieto Díaz ${ }^{\mathrm{a}, \mathrm{k}}$, I. Cáceres ${ }^{1}$, E. Allué ${ }^{\mathrm{l}}$, M.D. Marín Monfort ${ }^{\mathrm{a}}, \mathrm{T}_{\text {. Sanz Martín }}^{\mathrm{a}}$ \\ ${ }^{a}$ Museo Nacional de Ciencias Naturales (CSIC), José Gutiérrez Abascal, 2. 28006 Madrid, Spain \\ binstitute of Man. 25 Davitashen, 375108, 025 Yerevan, Armenia \\ 'The Natural History Museum, Cromwell Road, London SW7-5BD, UK \\ ${ }^{d}$ Institute of Molecular Biology, National Academy of Sciences, 7, Hasratyan Street, 014 Yerevan, Annenia \\ 'Institute of Archaeology and Ethnography, 15, Charen Street, $\mathbf{0 2} 25$ Yerevan, Annenia \\ i National University of Ireland, Galway, University Road, Galway, Ireland \\ ${ }^{g}$ Universidad Complutense de Madrid, José Antonio Novais, 2, Cudad Universitaria, 28040 Madrid, Spain \\ btate University of Arstakh, Nagomo-Karabagh \\ 'Research Laboratory for Archaeology and the History of Art, University of Oxford, Dyson Perrins Building, South Parks Road, Oxford OXI 3QY', UK \\ ${ }^{J}$ Escuela Técnica Superior de Ingenieros de Minas, Ríos Rosas 21, 28003 Madrid, Spain \\ "Molecular Neuroprotection Lab, Hospital Nacional de Parapléjicos (SESCAM), Toledo, Spain \\ IInstitut de Paleoecologia Humana i Evolució Social- Universitat Rovira i Virgili. Plaça Imperial Tarraco, 1, 43005 Tarragona, Spain
}

Azokh Cave is located near the village of the same name in the Nagorno-Karabagh region of the south-eastern part of the Lesser Caucasus (39³7.09' N and 46 59.19' E, 962 metres -a.s.l.). Azokh Cave and other relevant Acheulian sites in the Caucasus (Fig. 1) were described by Lioubine (2002). Together with Mousterian sites (Klein, 1969, 1999; Hoffecker and Cleghorn, 2000; Hoffecker, 2002; Stringer and Andrews, 2005) and sites producing evidence of the Middle-Late Palaeolithic transition (Joris and Adler 2008), the Caucasus region has provided evidence of continuous human settlement of the area throughout the Pleistocene. The geographical location of these sites indicates the persistence of a natural corridor that Lioubine (2002) named the 'Caucasus isthmus' and which we describe as the Trans-Caucasian corridor.

Based on a geological survey of Quaternary deposits in collaboration with the Armenian Academy of Sciences (Fernández-Jalvo et al., 2004; King et al., 2003), we observe that the topography of the area has changed considerably due to tectonic compression and periglacial isostasy. This is in agreement with estimations by GPS studies (Mosar, 2006, Mosar et al., 2007) and ESR (Grün et al., 1999) that established an uplift rate of 12 to $14 \mathrm{~mm} /$ year or $0.8-1.0 \mathrm{~cm} / \mathrm{year}$,

\footnotetext{
* Corresponding author.

E-mail address: yfj@mncn.csic.es (Y. Fernández-Jalvo).
}

respectively. The corridor has changed greatly since the middle Pleistocene, with uplift and erosion altering the landscape, but it is likely that passage through the Caucasian mountains has always been possible. The Trans-Caucasian corridor and other routes via Turkey and towards Asia (Bar-Yosef and Belfer-Cohen, 2001) were migration pathways during the Pleistocene.

Fossil humans in the Caucasian area are scarce. The site of Dmanisi in Georgia yielded the earliest lnown Eurasian hominins (1.7 Ma, Gabunia et al., 2000; Rightmire et al., 2006; MartinónTorres et al., 2008). Late surviving Neanderthals are present at several sites: Mezmaiskaya Cave, in the Northern Caucasus of Russia (30 ka, Skinner et al, 2005), provided remains of late surviving Neanderthals; a mandible of a 2-3 year old Neanderthal child was found at Barakay Cave (North Caucasus; Lubin et al., 2002). Two incisor fragments and one premolar from Kudaro I may be human (Lioubine, 2002). In this context, Azokh Cave fills an important temporal gap. Azokh Cave contains a nearly continuous stratigraphic section from $>300 \mathrm{ka}$ to the present, and mandible fragments of Homo heidelbergensis found at the site (Kasimova, 2001) represent the easternmost extent of this species. Here we review the finds of this long forgotten site and present results of our recent work.

\section{Azokh Cave excavations 1963-1988 and 2002-present}

M.M. Huseinov discovered Azokh Cave in 1960 (Huseinov, 1985 cited in Lioubine, 2002; Mustafayev, 1996; then named as Azykh Cave). One human mandible fragment found in 1968 was shown to be a middle Pleistocene pre-Neanderthal similar to that from Arago (Kasimova 2001). This specimen, together with the abundant faunal remains and stone tools recovered from these extensive excavations, are currently housed at The Natural-Historical 


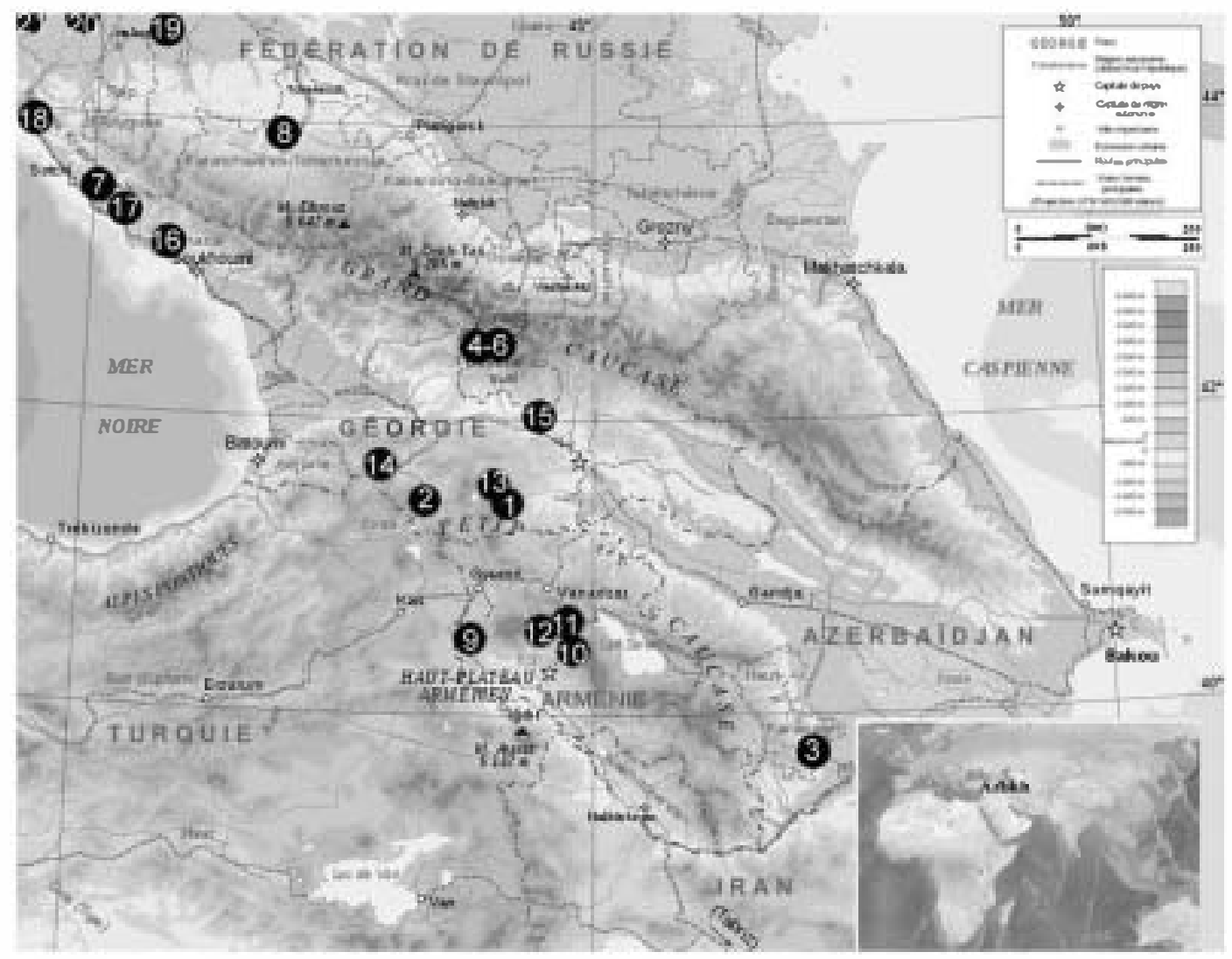

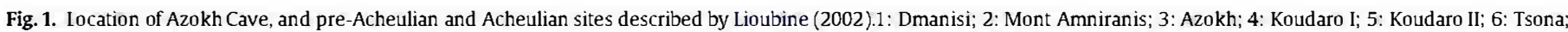

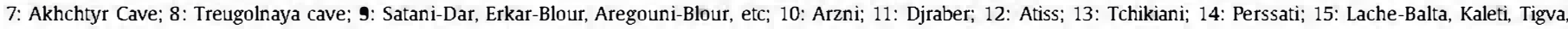
Gorisstavi, etc; 16: Yachtoukh, Gvard, Otap, etc; 17: Bogoss; 18: Cap de Kadoch; 19: Abadzekhaya, Chakhanskaja, etc; 20: Ignatenkov koutok; 21: Abin.

Museum and Medical University of Baku in Azerbaijan. The site was intensively dug during this first period, leaving intact about $970 \mathrm{~m}^{3}$ at the back of the cave from the original volume of about $3400 \mathrm{~m}^{3}$ (Fig. 2). Lioubine (2002) claims that for the first 15 years of excavation, the work and finds (including the human mandible [Kasimova, 2001]) were not properly documented and lacked an interdisciplinary approach. The excavations were interrupted by the Nagorno-Karabagh conflict in 1989, but an armistice proposed in 1994 has held to this day.

The Azokh Cave project was resumed by an international and multidisciplinary research group in 2002 at the invitation of the Government of Nagorno Karabagh. We installed an aerial grid to establish a permanent spatial reference for location of squares and began systematic excavations. Stratigraphic beds were identified, measured, and described (Fig. 2), and the topographyof the entire cave system was measured and mapped. During this geological work, four more cave entrances were discovered, two of which (Azokh 2 and Azokh 5) contain palaeontological and archaeological material (Fig. 3).

\section{Results}

\section{Stratigraphy of Azokh 1}

Our investigations of Azokh 1 shows that the remaining (intact) stratigraphy is divided into two sequences which are no longer physically connected. The upper sequence (Beds I-V) is fossiliferous and contains macro- and micro-fauna as well as evidence of human occupation. The lower part of the sequence contains a transported unit (Bed VI), and several beds (VII to XI) which may have formed under vadose conditions and do not appear to contain Pleistocene fossils.
From top to bottom, the upper fossiliferous sequence is (Murray et al., under revision)

- Bed I (1.35-1.5 m thick) is present close to the top of the unit. This fumière was created by the burning of discarded food remains and animal excrement which had accumulated when animals were kept in the cave. Pottery and late Palaeolithic tools are present within this hearth. Unfortunately, there is a distinctive erosive discordance between Bed I and Bed II that obscures the transition between Middle and Late Palaeolithic.

- Bed II (c. $1 \mathrm{~m}$ thick) is a reddish grey-brown calcareous sandy loam. This unit shows strong diagenetic alteration (Lynch et al., in preparation), including newly formed minerals (Tinslayte, $\mathrm{KAl}_{2}\left(\mathrm{PO}_{4}\right)_{2}(\mathrm{OH}) \cdot 2\left(\mathrm{H}_{2} \mathrm{O}\right)$ related to bat guano; Magela da Costa and Rúbia Ribeiro, 2001; Marincea et al., 2002). This diagenesis has seriously affected fossil bone preservation at certain areas of the excavation surface. A large, stone-based hearth with associated fossils (mainly Ursus spelaeus), Levallois and non-Levallois, Middle Palaeolithic stone tools (Moloney et al., under revison; Moloney et al., in preparation), and cumarked bones are present.

- Bed III (c. $0.6 \mathrm{~m}$ thick) is a medium tan-brown clay. The excavation yielded abundant fossils (mainly cave bears, Ursus spelaeus) and Middle Palaeolithic stone tools associated with ashes and charcoal.

- Bed IV (1.1-1.18 m thick) is a friable medium greyish-brown calcareous clay. This unit yielded Ursus spelaeus remains and other herbivore fossils (Made et al., in preparation) bearing cut marks related to human butchery.

- Bed V (c. $4.5 \mathrm{~m}$ thick) is a reddish-brown clay loam unit in which the partial mandible of Homo heidelbergensis was found (Huseinov, 1985 in Lioubine, 2002). Ursus spelaeus is common 


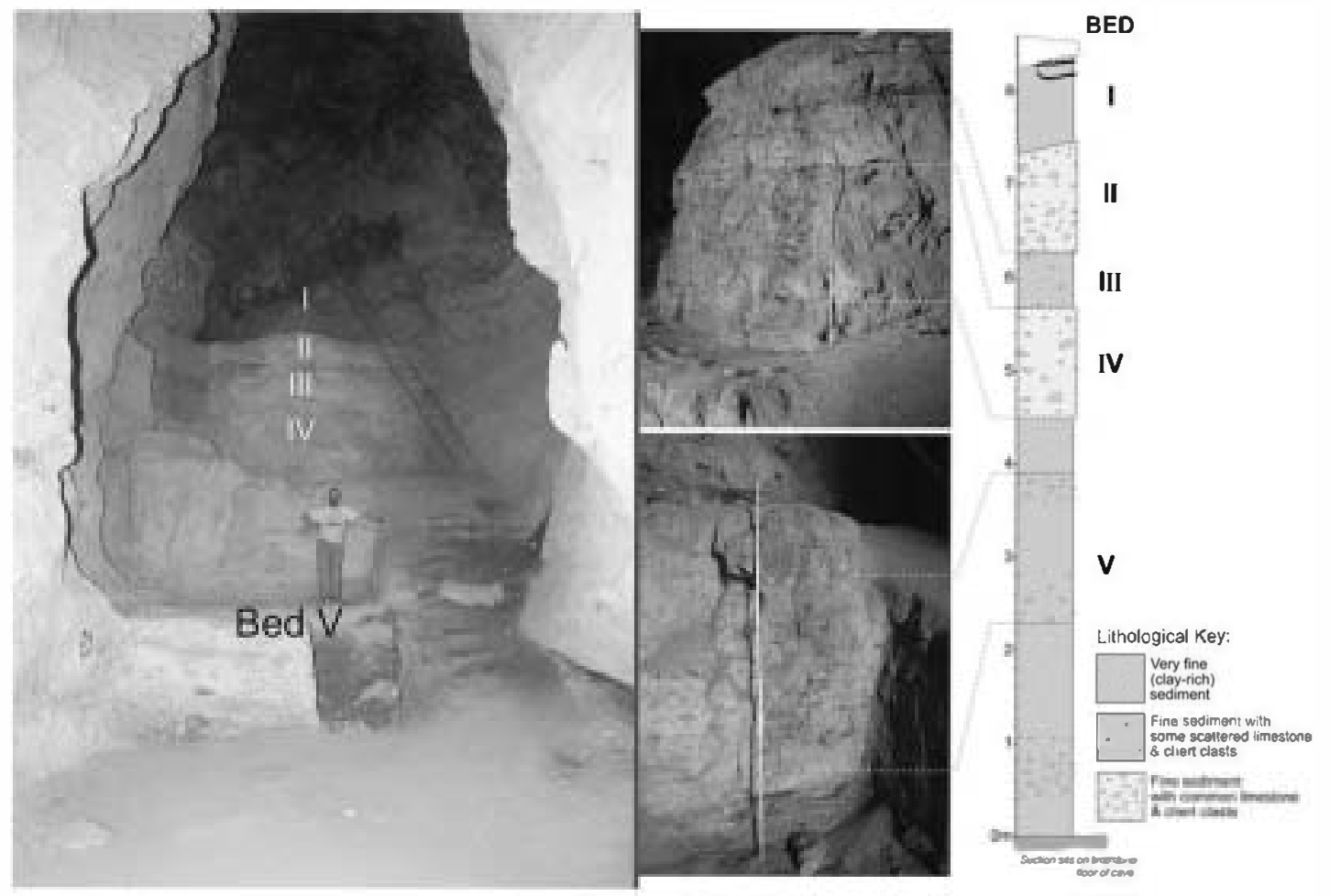

Fig. 2. Left: Photos of the Azokh I upper sequence. Right: Composite stratigraphic log of fossiliferous Beds VI to I.

in this unit as is Cervus elaphus. Stone tools from this bed appear to be Acheulian, although the recovered pieces are not fully diagnostic.

\section{Azokh I archaeological and paleontological remains}

The most abundant macro- and micro-mammals are Ursus spelaeus (Made et al., in preparation) and a great diversity of bats (Sevilla and Dominguez, in preparation), respectively. A variety of cervids and bovids (Cervus elaphus, Dama,Capra aegagrus) as well as tortoise, lagomorphs, rodents, reptiles, and amphibians are present in all units. Iarge felids (Panthera pardus), canids (Canis Jupus, Vulpes vulpes), and bison are present in Bed II; rhino (Stephanorhinus) and badger are present in Bed IV; wolf, jackal, and hyaena (Crocuta crocuta), Megaloceros, and roe deer are present in Bed V, and wild pigs (Sus scrofa) have been identified in certain units so far (Made et al., in preparation; Parfitt et al., in preparation). The analysis of detailed sampling every $20 \mathrm{~cm}$ for starch and pollen is underway, as well as phytolith and pollen analysis from bear coprolites (Hardy and Moloney, in preparation; Scott et aI., in preparation). Charcoal associated with hearths is under study as well (Allué, in preparation).

Almost all units show evidence of human involvement (Fig. 4), either as occupation levels or of intermittent visits to exploit animals living in the cave. Faunal remains recovered from human occupation levels consist mainly of low meat and low marrowbearing elements, including numerous fibulae, hand, and foot bones, in particular in Bed IV and Bed Ill. Most elements are complete and many exhibit cutmarks. Bones are associated with some stone tools in Bed III, but Bed IV has not provided stone tools thus far. This pattern suggests that those bones that were not worth transporting due to low nutritional content were abandoned in the cave (Marín et al., in preparation). In Bed II this pattem changes slightly. This unit yields complete large limb bones of bears rich in marrow content together with highly broken bones and stone tools. This pattern suggests that some carcasses of bears found in the cave after hibernation were abandoned perhaps due to an advanced level of decay. In contrast, Bed V shows bear and herbivore bones, as well as stone tools, scattered and dispersed, showing no clear pattern of occupation.

The lithic assemblages are primarily Middle Palaeolithic in character (Beds III and II), although there is possibly some indication of Acheulian technology in Bed V and one classic Upper Palaeolithic end scraper found in the contact area between Beds I and II. The small assemblage from Bed V consists mainly of retouched scrapers and unretouched flakes; no bifaces or chopper/ chopping tools have been found so far, nor is there any indication of the use of Ievallois technology in Bed V. The non-cortical nature of most pieces suggests that initial stages of working took place elsewhere. The few lithics from Bed III show Middle Palaeolithic affinities and include flakes and a non-prismatic blade. The largest lithic assemblage from Bed II includes retouched and unretouched flakes, a few blades, points and cores, and is Mousterian with a Levallois component (Moloney et al., under revision; Moloney et al., in preparation), suggesting perhaps the involvement of Neanderthals. Raw materials exploited for stone tool manufacture are primarily cave chert and a range of siliceous materials from nearby river gravels, but also include some use of non-local limestone, quartzite, quartz, basalt, and obsidian. (Moloney et al., under revision; Moloney et al., in preparation).

Excavations in Azokh 1 show that sediments were derived from within the cave system and that the stratigraphic sequence represents a considerable span of time. Unfortunately, the cave is and has been intensively inhabited by bats producing large amounts of guano and this has been the case for some time now. Apart from physical surface damage of some fossils in Bed II, guano has likely caused the complete absence of carbon content in bones from Bed I (Fig. 4), thereby affecting carbon radiometric dating attempts (Ditchfield et al., in preparation). Only charcoal has proven 

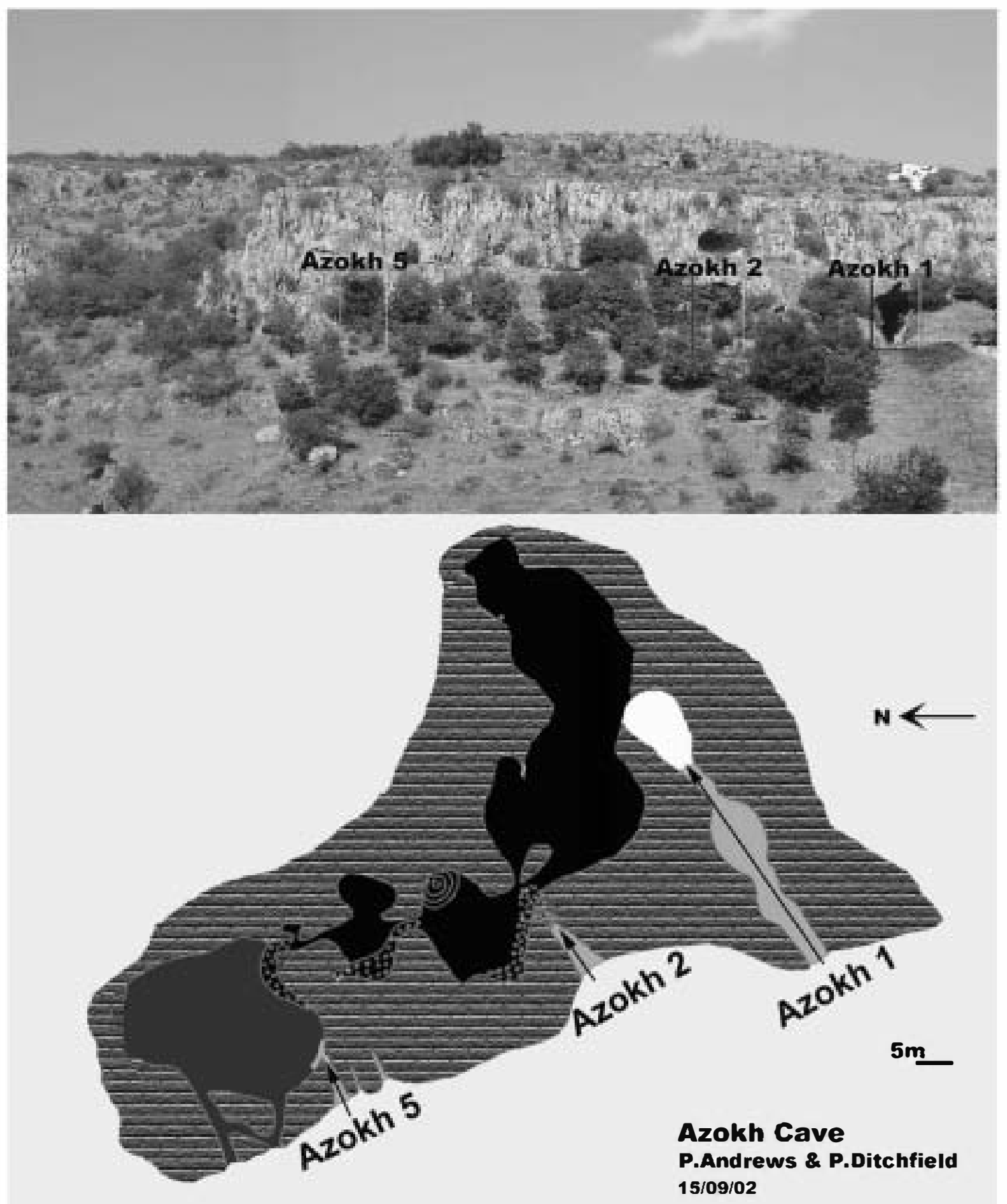

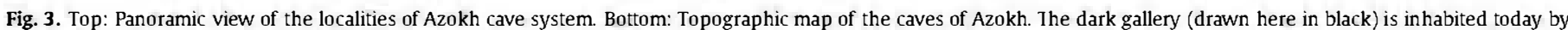

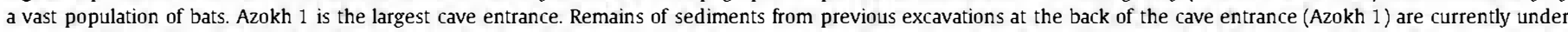

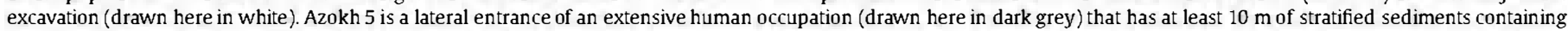
faunal and human fossils and tools.

to have enough carbon to be dated. Charcoal recovered from the fumière at Bed $I$ has provided an uncalibrated AMS age in radiocarbon years BP of $157 \pm 26$ years (1785 cal AD_OxA-19424). It is likely that Bed $\mathrm{I}$ is the result of the Azokh population periodically seeking refuge in the cave during conflicts since the 18th century. Electron spin resonance (ESR) of a single bone in Bed III provided an age of $-208 \pm 27$ ka (Grün, pers.comm.). Various means of dating the hominin-bearing Bed $V$ have yielded a range of middle Pleistocene ages. Uranium series age estimates are in the range of $\sim 200$ ka (Pike, pers. comm.), whereas amino-acid racemization (D/LAsp;
Fernández-Jalvo et al., 2004) and ESR suggest an age of around $300 \mathrm{ka}$ for Bed V (Grün, pers. comm.) These ages are especially important in view of the hominin remains uncovered from this unit that were previously suggested to have an age of 350-400 ka (Huseinov, 1985 in Lioubine, 2002, Kasimova 2001).

\section{Azokh 2 archaeological remains}

Azokh 2 is a smaller cave entrance to the north of Azokh 1 Cave (Fig. 3). The geomorphology and nature of the upper sedimentary 

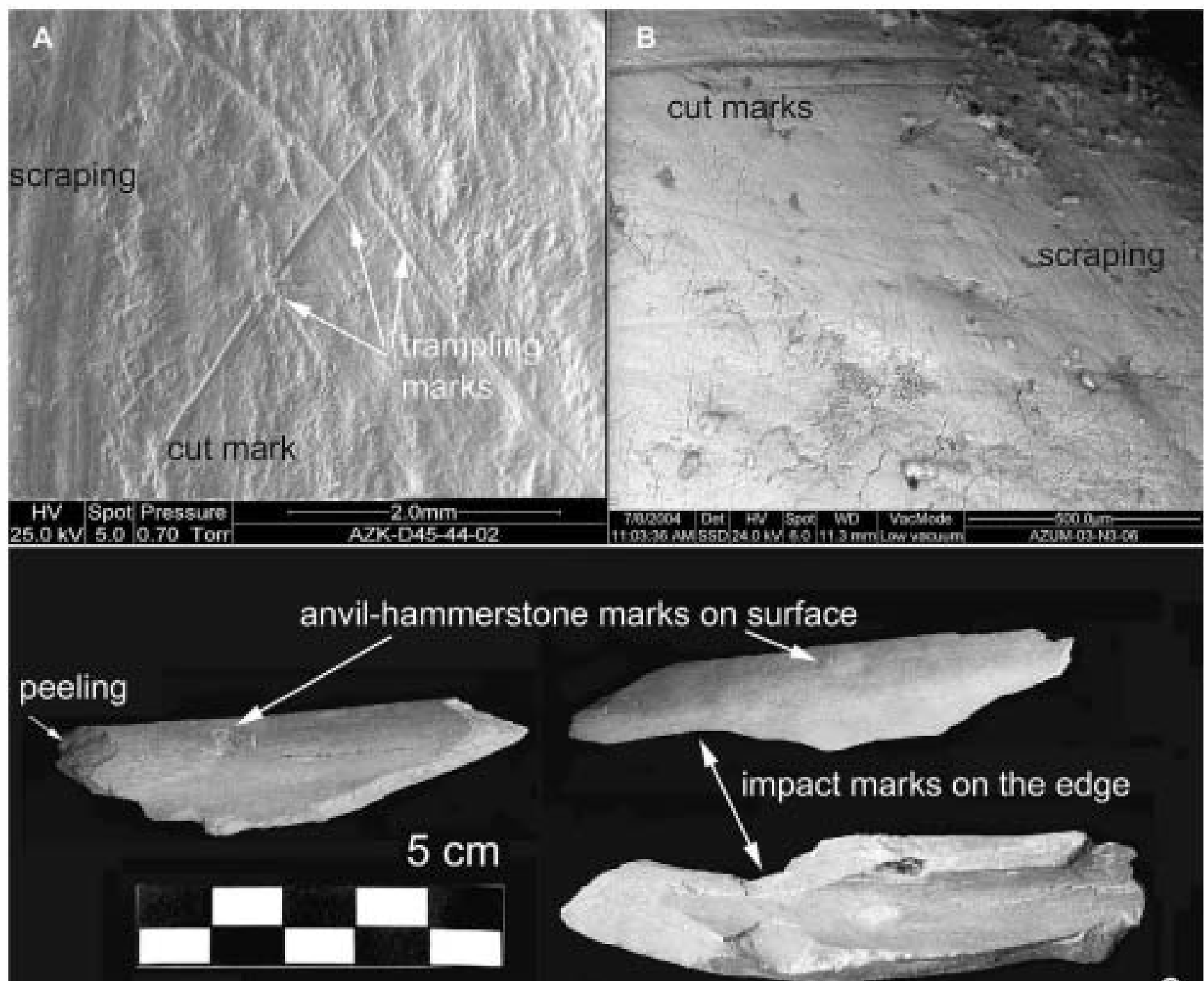

C
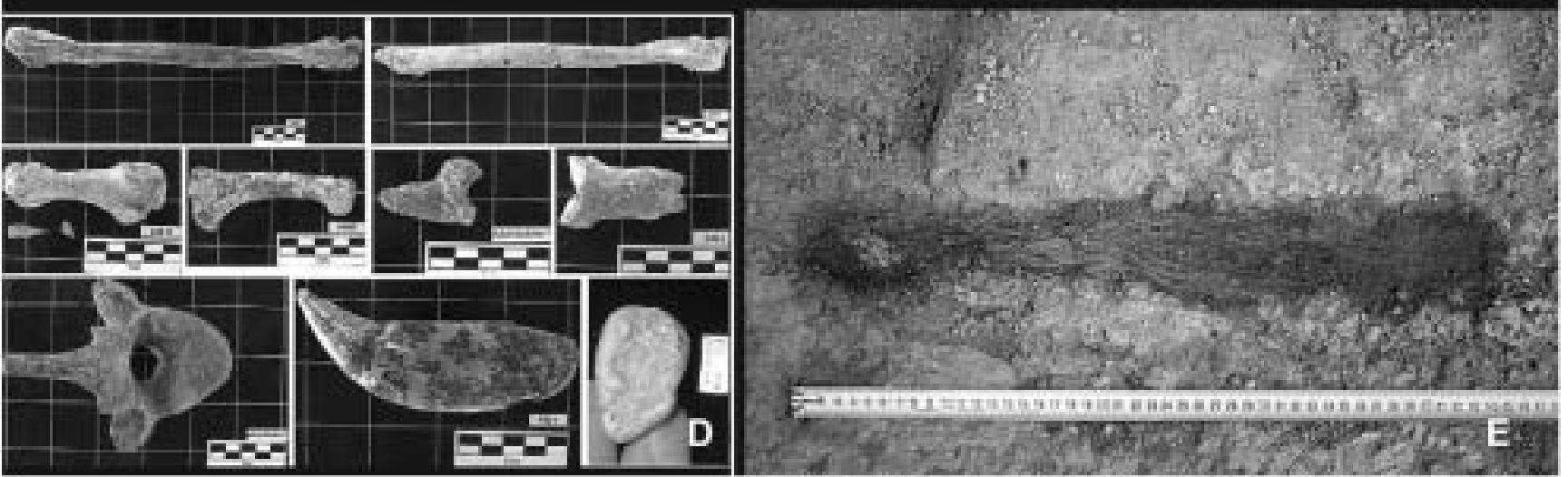

Fig. 4. A and B: SEM microphotographs of a deer bone bearing cut marks, scraping marks, and more recent trampling marks. C: Human induced damage on fossil bones. D: Several bones poor in marrow content (e.g., fibulae, metapodial, or phalanges) found complete, with some bearing cut marks on surface. E: Poorly preserved fossil from Azokh 1, Bed II likely due to highly acidic bat guano.

fill of this chamber are similar to Azokh 1. The upper units of Azokh 2 contain sediments similar to those of Bed $I$ in Azokh 1 Cave. In previous excavations, pottery and artefacts from the Middle Ages to the Bronze Age were recovered in Azokh 1 (Lioubine, 2002). In 2007, a modern human skeleton in anatomical position but without grave goods was recovered from Azokh 2
(King et al., in preparation). AMS radiocarbon age estimate of this skeleton is $1265 \pm 23$ y BP (780 calAD_OxA-18875). The absence of artefacts or grave goods may suggest the possibility of an accidental death. The upper sedimentary layers also contain reused hearths (Sanz et al, in preparation), as well as pottery, obsidian, and butchered domestic animal bones. 
provided over the years. We are very grateful for financial support

The entrance to Azokh 5 is a narrow passage leading to a lateral section of previously-untouched fossiliferous and archaeological deposits. This new entrance provides direct access to the largest chamber (about $500 \mathrm{~m}^{2}$ ) within the Azokh Cave system (Fig. 3) and the possibility of a rich human occupation similar to Azokh 1 . Electric resistivity tomography has shown over $10 \mathrm{~m}$ of sediments to be present (Dominguez et al., in preparation). A test trench ( $2 \times 1 \mathrm{~m}$ wide and $3-4 \mathrm{~m}$ deep) allows us to distinguish four stratigraphic beds (A to D) from top to bottom. Bed A yielded modern human remains (teeth and cranial fragments) with associated charcoal that has been radiocarbon dated to $\sim 2300$ years $\mathbf{B P}$ (384calBC_OxA 17589). These sediments could be related to finds from the bottom of Bed I from Azokh 1, where Lioubine (2002) referred to Bronze to Middle Age artefacts recovered by previous excavations. In addition, fossils of bears, suids, small canids, carnivore coprolites, tortoises, bats, lagomorphs, rodents, birds, and amphibians have been found in these sediments. Most interestingly, cutmarks are present on some large cervids and on a rhino medial phalanx from the bottom of the section exposed in Azokh 5 .

\section{Conclusions}

Azokh Cave is located in a corridor through the Caucasus that allowed migration of humans and other fauna into Europe and Asia during the Pleistocene. The easternmost representative of $H$. heidelbergensis was uncovered in Bed V of Azokh by Azerbaijani and Russian archaeologists. Investigations by our group provide new geological age estimates and information about Pleistocene fauna and human behaviours. Past and present work in Azokh Cave shows that this was an important settlement area for humans from the Pleistocene through Holocene times.

The continuous sequence of Azokh I from Bed V (H. heidelbergensis) up to Beds IV-II (Neanderthals) indicates the presence of these two human species. Further information about the palaeoecology and local evolution of the landscape (Andrews et al., in preparation) can be obtained from these sites. Information about the transition of the local Acheulian into the Mousterian and the emergence of Levallois technique has been provided by research at Azokh Cave. In addition, two new fossiliferous sites (Azokh 2 and 5) constitute a rich source of information, as these new sites may have a better record of the Middle to Late Palaeolithic transition than does Azokh 1. The Azokh Cave complex should continue to provide relevant information about human evolution and the prehistory of human occupation in the Trans-Caucasian corridor.

\section{Acknowledgments}

We are extremely grateful for the extensive support this project has received from the authorities in Nagorno-Karabagh and for their permission to work at this site. We thank Dr. Melanya Balayan, Director of the Artsakh State Museum of History and Country Study and staff at this museum, for the loan of material for study and restoration. We are extremely grateful to Dr. S. Hayrabetyan for his technical advice. We thank our local field assistants and the villagers of Azokh who help support the project in different ways and without whom this work would not be possible. We are grateful to a number of institutions for funding and academic support provided to this work - the Museo Nacional de Ciencias Naturales (CSIC), and The Spanish Ministry of Science and Education that partially financed associated research projects (BTE20001309, BTE2003-01552; BTE 2007-66231); The Graduate School, University College London; and The University of Galway. We thank AGBU (London Trust) for the continued financial support it has that has been provided by three anonymous donors. We finally thank Susan Antón, Fred Spoor, and anonymous reviewers for their comments and suggestions that greatly improved this paper.

\section{References}

Allué, E. Charcoal. In: Fernández-Jalvo, Y., Andrews, P., King, T., Yepiskoposyan, L. (Eds), Azokh Cave and the Transcaucasian Corridor. Vertebrate Paleobiology and Paleoanthropology Book Series. Springer, Dordrecht, in preparation.

Andrews, P., Hixson, S., Nieto, M., King, T., Asryan, L., Yepiskoposyan, L., FernándezJalvo, Y. Palaeocology. In: Fernández-Jalvo, Y., Andrews, P., King, T., Yepiskoposyan, L. (Eds), Azokh Cave and the Transcaucasian Corridor. Vertebrate Paleobiology and Paleoanthropology Book Series. Springer, Dordrecht, in preparation.

Bar-Yosef, ๑., Belfer-Cohen, A., 2001. From Africa to Eurasia, early dispersals. Quatern. Int $75,19-28$.

Ditchfield, P., Grün, R, Torres, T., Murray, J., Domínguez, P., Fernández-Jalvo, Y. Dating. In: Fernández-Jalvo, Y., Andrews, P., King, T., Yepiskoposyan, L. (Eds), Azokh Cave and the Transcaucasian Corridor. Vertebrate Paleobiology and Paleoanthropology Book Series. Springer, Dordrecht, in preparation.

Dominguez, P., Murray, J., Aracil, E., Porres, J.A., Andrews, P. Geomorphology and 3D cave reconstruction. In: Fernández-Jalvo, Y., Andrews, P., King, T., Yepiskoposyan, L. (Eds), Azokh Cave and the Transcaucasian Corridor. Vertebrate Paleobiology and Paleoanthropology Book Series. Springer, Dordrecht, in preparation.

Fernández-Jalvo, Y., King, T., Andrews, P., Moloney, N., Ditchfield, P., Yepiskoposyan, L, Safarian, V., Nieto Díaz, M., Melkonyan, A., 2004. Azokh Cave and Northern Armenia. In: Baquedano, E., Rubio Jara, S. (Eds.), Miscelanea en Homenaje a Emiliano Aguirre, vol. IV. Museo Arqueológico Regional series, Arqueología. Alcalá de Henares, pp. 158-168.

Gabunia, L, Vekua, A., Lordkipanidze, D., Swisher Ill, C.C., Ferring, R, Justus, A., Nioradze, M., Tvalchrelidze, M., Antón, S., Bosinski, G., Jöris, •., De Lumley, M.A., Majsuradze, G., Mouskhelishvili, A., 2000. Earliest pleistocene hominid cranial remains from Dmanisi, Republic of Georgia: taxonomy, geological setting, and age. Science 288, 1019-1025.

Grün, R, Tani, A., Gurbanov, A., Koshchug, D., Williams, I., Braun, J., 1999. A new method for the estimation of cooling and denudation rates using paramagnetic centres in quartz: a case study on the Eldzhurtinskiy Granite, Caucasus. J. Geophys. Res. 104 (B8), 17531-17549.

Hardy, K., Moloney, N. Starches and phytoliths. In: Fernández-Jalvo, Y., Andrews, P., King, T., Yepiskoposyan, L. (Eds.), Azokh Cave and the Transcaucasian Corridor. Vertebrate Paleobiology and Paleoanthropology Book Series. Springer, Dordrecht, in preparation.

Hoffecker, J.F., 2002. Desolated Landscapes. Rutgers University Press, New York. pp. 298.

Hoffecker, J.F., Cleghorn, N., 2000. Mousterian hunting patterns in the northwestern Caucasus and the ecology of the Neanderthals. Int. J. Osteoarchaeol 10 , $368-378$.

Joris, ., Adler, D.S., 2008. Setting the record straight: Toward a systematic chronological understanding of the Middle to Upper Paleolithic boundary in Eurasia. J. Hum. Evol. 55, 761-763.

Kasimova, RM., 2001. Anthropological research of Azykh Man osseous remains. Hum. Evol. 16, 37-44.

King, T., Fernández-Jalvo, Y., Moloney, N., Andrews, P., Melkonyan, A., Ditchfield, P., Yepiskoposyan, L., Karapetyan, S., 2003. Exploration and survey of Pleistocene Hominid Sites in Armenia and Karabagh. Antiquity 77s. http://antiquity.ac.uk/ projgall/king/king.html.

King, T., Andrews, P., Yepiskoposyan, L., Geigl, E-M., Asryan, L., Fernández-Jalvo., Y. Humans at and from Azokh Caves. In: Fernández-Jalvo, Y., Andrews, P., King, T., Yepiskoposyan, L. (Eds.), Azokh Cave and the Transcaucasian Corridor. Vertebrate Paleobiology and Paleoanthropology Book Series. Springer, Dordrecht, in preparation.

Klein, RG., 1969. Mousterian Cultures in European Russia. Science 165, 257-264.

Klein, R.G., 1999. The Human Career. University Chicago Press, Chicago.

Lioubine, V.P., 2002. L'Acheuléen du Caucase. ERAUL 93. Études et Recherches Archéologiques de I'Université de Liège, Liège.

Lubin, V.P., Zubov, A.A., Romanova, G.P., Kharitonov, V.M., 2002. Barakay mousterian cave site in the Northern Caucasus. Hum. Evol. 17, 215-230.

Lynch, E., Murray, J., Dominguez, P., Williams, D.M., Fernandez-Jalvo, Y. Geochemistry and Diagenesis. In: Fernández-Jalvo, Y., Andrews, P., King, T., Yepiskoposyan, L. (Eds.), Azokh Cave and the Transcaucasian Corridor. Vertebrate Paleobiology and Paleoanthropology Book Series. Springer, Dordrecht, in preparation.

Made, J. van der, Torres, T., King, T., Fernández-Jalvo, Y. Large mammals: Herbivores, Carnivores and Cave Bears. In: Fernández-Jalvo, Y., Andrews, P., King, T., Yepiskoposyan, L. (Eds.), Azokh Cave and the Transcaucasian Corridor. Vertebrate Paleobiology and Paleoanthropology Book Series. Springer, Dordrecht, in preparation.

Magela da Costa, G., Rúbia Ribeiro, V., 2001. The occurrence of tinsleyite in the archaeological site of Santana do Riacho. Brazil. American Mineralogist 86, $1053-1056$. 
Marín, M.D., Fernández-Jalvo, Y., Cáceres, I., Andrews, P. Taphonomy. In: FernándezJalvo, Y., Andrews, P., King, T., Yepiskoposyan, L. (Eds.), Azokh Cave and the Transcaucasian Corridor. Vertebrate Paleobiology and Paleoanthropology Book Series. Springer, Dordrecht, in preparation.

Marincea, S., Dumitras, D., Gibert, R, 2002. Tinsleyite in the "dry" Gioclovina Cave (Sureanu Mountains, Romania): the second occurrence. E.J.M 14, 157-164.

Martinón-Torres, M., Bermúdez de Castro, J.M., Gómez-Robles, A., Margvelashvili, A., Prado, L., Lorkipanidze, D., Vekua, A., 2008. Dental remains from Dmanisi (Republic of Georgia): morphological analysis and comparative study. J. Hum. Evol. 55, 249-273.

Moloney, N., Fernández-Jalvo, Y., Hovsepian-King, T., Murray, J., Asryan, L., Andrews, P., Dominguez-Alonso, P., Yepiskoposyan, L. The lithic assemblages from Azokh I cave, the Lesser Caucasus: 2002-2008 excavations. Antiquity (ref number: 2009/88), under revision.

Moloney, N., Asryan, L, Fernandez-Jalvo, Y. Lithics. In: Fernández-Jalvo, Y., Andrews, P., King, T., Yepiskoposyan, L. (Eds.), Azokh Cave and the Transcaucasian Corridor. Vertebrate Paleobiology and Paleoanthropology Book Series. Springer, Dordrecht, in preparation.

Mosar, J., 2006. The Eastern Greater Caucasus - Uplift, topography and tectonics. Geophys. Res. Abstracts 8, 04329

Mosar, J., Glasmacher, U.A., Kangarli, T., Bochud, M., Rast, A., 2007. Mountain building in the Greater Caucasus: topography and Uplift/exhumantion. Geophys. Res. Abstracts 9, 07863.

Murray, J., Domínguez-Alonso, P., Fernández-Jalvo, Y., King, T., Andrews, P., Yepiskoposyan, L, Moloney, N., Lynch, E.P., Asryan, L, Ditchfield, P., Williams, D.M. Pleistocene to Holocene statigraphy of Azokh Cave, Lesser Caucasus. Geoarchaeology, under revision.
Mustafayev, A., 1996. Jawbones and Dragon Legends, Azerbaijan's Prehistoric Azikh Cave. Available at. Azerbaijan International 4 (2), 24-29. http://www.azer.com/ aiweb/categories/magazine/42_folder/42_articles/42_azikhcave.html.

Parfitt, S. Blain, H.A., King, T. Rodents and reptiles. In: Fernández-Jalvo, Y., Andrews, P., King, T., Yepiskoposyan, L. (Eds.), Azokh Cave and the Transcaucasian Corridor. Vertebrate Paleobiology and Paleoanthropology Book Series. Springer, Dordrecht, in preparation.

Rightmire, G.P., Lordkipanidze, D., Vekua, A., 2006. Anatomical descriptions, comparative studies and evolutionary significance of the hominin skulls from Dmanisi, Republic of Georgia. J. Hum. Evol. 50, 115-141.

Sanz, T., Gómez, J., Márquez, B., Asryan, L., Yepiskoposyan, L., Simonyan, H., Moloney, N. Ceramics. In: Fernández-Jalvo, Y., Andrews, P., King, T., Yepiskoposyan, L. (Eds.), Azokh Cave and the Transcaucasian Corridor. Vertebrate Paleobiology and Paleoanthropology Book Series. Springer, Dordrecht, in preparation.

Scott, L., Torres, T., Fernández-Jalvo, Y., (in prep). Coprolites and pollen record. In: Fernández-Jalvo, Y., Andrews, P., King, T., Yepiskoposyan, L. (Eds.), Azokh Cave and the Transcaucasian Corridor. Vertebrate Paleobiology and Paleoanthropology Book Series. Springer, Dordrecht, in preparation.

Sevilla, P., Domínguez, P., (in prep) Bats. In: Fernández-Jalvo, Y., Andrews, P., King, T., Yepiskoposyan, L. (Eds.), Azokh Cave and the Transcaucasian Corridor. Vertebrate Paleobiology and Paleoanthropology Book Series. Springer, Dordrecht, in preparation.

Skinner, A.R., Blackwell, B.A.B., Martin, S. Ortega, A., Blicksteinm, J.IB., Golovanona, L.V., Doronichev, V.B., 2005. ESR dating at Mezmaiskaya Cave, Russia. Appl. Radiat. Isot. 62, 219-224.

Stringer, C., Andrews, P., 2005. The Complete World of Human Evolution. Thames and Hudson, London. 